\title{
Peningkatan Kemampuan Pemecahan Masalah pada Materi Persamaan Garis Singgung Lingkaran melalui Pembelajaran Discovery Learning
}

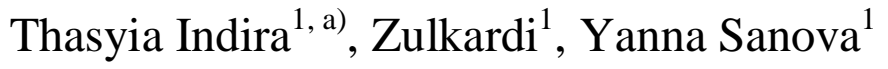 \\ ${ }^{1}$ Universitas Sriwijaya \\ a) thasyiaaa@yahoo.com
}

\begin{abstract}
This study aimed to improve student's problem-solving abilities of tangent circle equation using discovery learning. This research was done in class XI IPA 4 SMA N 1 Palembang. This research method is used Classroom Action Research with discovery learning models. The instrument is used test instrument in the form of an evaluating matter of the tangent circle equation in the description form and the observation sheet for observation of the learning activity of the students. The results of the study showed that there is an increase in students' problem-solving abilities in tangent circle equation material using discovery learning. This increase can be seen from the results of the post-test students with an average score of 93,6 which increased when compared with the results of the pre-test with an average value of 58,2. The percentage of students who complete learning increases from $30 \%$ pre-test to $100 \%$ at post-test with KKM (maximum mastery criteria) $\geq 70$. Based on the data analysis, it can be concluded that learning with discovery learning models can improve student learning outcomes in the tangent of circle equation material.
\end{abstract}

Keywords: problem solving, discovery learning, tangent of circle equation

\begin{abstract}
Abstrak. Penelitian ini bertujuan untuk meningkatkan kemampuan pemecahan masalah siswa materi persamaan garis singgung lingkaran menggunakan discovery learning. Penelitian ini dilakukan di kelas XI IPA 4 SMA Negeri 1 Palembang. Metode penelitian yang digunakan adalah penelitian tindakan kelas dengan menggunakan model discovery learning. Instrumen yang digunakan adalah instrumen tes berupa soal evaluasi materi persamaan garis singgung lingkaran berbentuk uraian dan hasil lembar observasi aktivitas siswa. Hasil penelitian menunjukkan bahwa terdapat peningkatan kemampuan pemecahan masalah siswa pada materi persamaan garis singgung lingkaran menggunakan pembelajaran discovery learning. Hal ini terlihat dari hasil post-test siswa dengan rata-rata nilai 93,6 mengalami peningkatan jika dibandingkan dengan hasil pre-test dengan rata-rata nilai 58,2 . Persentase siswa yang tuntas belajar meningkat dari $30 \%$ pre-test menjadi $100 \%$ pada saat post-test dengan $\mathrm{KKM} \geq 70$. Dari analisis data yang dilakukan dapat disimpulkan bahwa pembelajaran dengan pembelajaran discovery learning dapat meningkatkan hasil belajar siswa pada materi persamaan garis singgung lingkaran.
\end{abstract}

Kata kunci: pemecahan masalah, discovery learning, persamaan garis singgung lingkaran 


\section{PENDAHULUAN}

Pembelajaran matematika menuntut peserta didik untuk memiliki kemampuan pemecahan masalah. Kemampuan pemecahan masalah merupakan kemampuan yang harus dimiliki peserta didik sesuai dengan pembelajaran matematika pada kurikulum 2013 edisi revisi 2017 di pendidikan dasar dan pendidikan menengah, yaitu memecahkan masalah dan mengomunikasikan gagasan. Menurut Effendi (2012), kemampuan pemecahan masalah sangat penting dalam pembelajaran matematika, bukan saja untuk mereka yang di kemudian hari akan mendalami atau mempelajari matematika, melainkan bagi mereka yang akan menerapkannya pada pembelajaran atau bidang studi lain dan dalam kehidupan sehari-hari. Oleh karena itu, kemampuan pemecahan masalah perlu terus dilatih sehingga peserta didik dapat memecahkan masalah yang ia hadapi.

Pentingnya penguasaan kemampuan pemecahan masalah belum diiringi dengan prestasi siswa. Hal tersebut sesuai dengan fakta lapangan yang terjadi, salah satunya adalah hasil Programme Internationale for Student Assesment (PISA) tahun 2015. Berdasarkan hasil PISA 2015 walaupun posisi siswa Indonesia mengalami peningkatan dari PISA 2012 sebelumnya, namun secara umum masih terdapat 42,3\% siswa Indonesia yang posisinya berada di bawah level 2 yang berarti siswa Indonesia masih sangat kurang dalam memahami konsep-konsep dasar. Lebih daripada itu dilaporkan juga terdapat $8 \%$ partisipan dari seluruh dunia yang kemampuan berpikirnya pada level 5 dan 6 yakni siswa yang mampu dalam menyelesaikan pemecahan masalah yang dinilai baik, dari mereka yang sedikit ini $(8 \%)$ ternyata hanya $0.8 \%$ yang diisi dari siswa Indonesia (Pontianakpost, 2016).

Fakta yang ada menunjukkan bahwa kemampuan pemecahan masalah peserta didik dalam menyelesaikan masalah Persamaan Garis Singgung Lingkaran. Jawaban siswa terhadap soal kemampuan pemecahan masalah masih jauh dari kriteria ideal. Berdasarkan hasil analisis lembar jawaban siswa, rata-rata hasil tes dan ketuntasan belajar kurang dari $60 \%$ yang mencapai Kriteria Ketuntasan Minimal (KKM) 70 pada skala 100. Dengan didasari standar tersebut secara individu banyak peserta didik yang memiliki nilai di bawah KKM artinya banyak peserta didik yang belum tuntas dan secara klasikal belum mencapai ketuntasan belajar sebesar 75\% pada pembelajaran tersebut. Hal ini terjadi karena kurangnya kemampuan peserta didik dalam memahami masalah, merencanakan pemecahannya, menyelesaikan masalah sesuai rencana, dan memeriksa kembali prosedur dan hasil penyelesaiannya menyebabkan peserta didik kesulitan dalam memecahkan suatu permasalahan yang diberikan.

Dalam pembelajaran pada materi Persamaan Garis Singgung Lingkaran, guru hanya menyampaikan secara langsung rumus-rumus yang diperlukan untuk menyelesaikan Persamaan Garis Singgung Lingkaran tanpa memulainya dari aktivitas-aktivitas yang melibatkan peserta didik untuk menyelesaikan masalah dan tanpa melaui proses-proses pemecahan masalah. Peserta didik hanya berperan sebagai penerima dan lebih pasif pada saat proses pembelajaran. Untuk meningkatkan kemampuan pemecahan masalah matematis siswa, beberapa penelitian telah mencoba mencari solusi melalui berbagai cara (Ahmad, Deswita, Ningsih \& Syafriadi, 2018; Elita, Habibi, Putra \& Ulandari, 2019; Gunawan \& Putra, 2019).

Salah satu pendekatan yang dapat melibatkan aktivitas peserta didik secara aktif dalam memecahkan masalah dan membuat pembelajaran matematika menjadi bermakna adalah discovery learning. Menurut Muhamad (2017), discovery learning adalah pembelajaran yang menitikberatkan pada aktivitas peserta didik sehingga peserta didik memperoleh pengetahuan yang 
belum diketahuinya tidak melalui pemberitahuan, melainkan sebagian atau seluruhnya ditemukan sendiri.

Pada prinsipnya, discovery learning mempunyai prinsip yang sama problem solving. Tidak ada perbedaan yang prinsipil pada ketiga istilah ini, pada discovery learning lebih menekankan pada ditemukannya konsep atau prinsip yang sebelumnya tidak diketahui. Pembelajaran Discovery Learning guru berperan sebagai pembimbing dengan memberikan kesempatan kepada peserta didik untuk belajar secara aktif, sebagaimana pendapat guru harus dapat membimbing dan mengarahkan kegiatan belajar peserta didik sesuai dengan tujuan. Kondisi seperti ini ingin merubah kegiatan belajar mengajar yang teacher oriented menjadi student oriented.

Beberapa peneliti sebelumnya yang menggunakan pembelajaran discovery learning sebagai penelitiannya terkait kemampuan pemecahan masalah, diantaranya penelitian yang dilakukan oleh Sahrudin (2014) yang mengatakan terdapat hubungan antara pembelajaran discovery learning dengan kemampuan pemecahan masalah. Kemudian Wasilah, Murini \& Julinus (2018) dalam hasil penelitiannya menyatakan LAS berbasis discovery learning dapat membantu peserta didik dalam memahami materi lingkaran analitik karena sudah memenuhi aspek valid dan praktis sehingga dapat membantu peserta didik dalam mengerjakan soal cerita mengenai Lingkaran. Penelitian lain juga dilakukan oleh Putra, Syarifuddin \& Zulfah (2018) guna menerapkan pembelajaran penemuan terbimbing dengan bantuan lembar kerja peserta didik. Penelitian Rhamayanti (2019) mengungkapkan bahwa discovery learning berpangaruh positif terhadap hasil belajar secara umum, aktifitas dan respon siswa. Selain itu dengan berbantu Android Apps berbasis penemuan terbimbing, pemahaman konsep matematis siswa dapat meningkat secara signifikan (Ariyanto, Aditya \& Dwijayanti, 2019). Melalui penelitian ini diharapkan pembelajaran discovery learning dapat mampu meningkatkan kemampuan pemecahan masalah siswa.

\section{METODE}

\section{Populasi dan Sampel}

Metode yang digunakan pada penelitian ini adalah Penelitian Tindakan Kelas (Penelitian Tindakan Kelas). Penelitian berlangsung dalam beberapa siklus dimana masing-masing siklusnya memiliki tahapaan kegiatan, yaitu perencanaan, pelaksanaan tindakan, observasi serta evaluasi dan refleksi. Subjek penelitian ini adalah siswa kelas XI IPA SMA Negeri 1 Palembang yang terdiri dari 36 siswa namun sampel yang digunakan pada pemelitian ini hanya 20 orang siswa dikarenakan ada beberapa siswa yang tidak mengikuti salah satu siklus dalam penelitian ini sehingga sampel yang digunakan hanya 20 orang siswa. Data pada penelitian ini diperoleh melalui hasil tes kemampuan pemecahan masalah siswa dan observasi aktivitas siswa pada proses pembelajaran.

\section{HASIL DAN PEMBAHASAN}

\section{Hasil Penelitian}

Penelitian Tindakan Kelas (PTK) ini dilaksanakan di SMA Negeri 1 Palembang dengan menerapkan model pembelajaran discovery learning. Subjek pada penelitian ini adalah siswa kelas XI IPA 4 SMA Negeri 1 Palembang tahun ajaran 2018/2019 yang berjumlah 36 orang yang terdiri dari 14 laki-laki dan 22 perempuan. Namun yang disajikan sampel pada penelitian ini hanya 20 orang siswa dikarenakan terdapat beberapa siswa yang hanya mengikuti siklus I dan siklus II saja. Pengambilan data dilakukan pada semester genap tahun ajaran 2018/2019 pada bulan Februari 
2019. Penelitian ini dilaksanakan dalam dua siklus masing-masing siklus terdiri dari dua kali pertemuan.

Data hasil belajar siswa sebelum diberikan tindakan diperoleh dari hasil pretest siswa pada materi persamaan garis singgung lingkaran dengan rata-rata seperti pada Tabel 1.

Tabel 1. Hasil Pre-Test

\begin{tabular}{ccc}
\hline Rentang Nilai & Jumlah Siswa & Kriteria \\
\hline $80-100$ & 2 & Sangat Baik \\
\hline $66-79,9$ & 8 & Baik \\
\hline $56-65,9$ & 10 & Cukup \\
\hline $40-55,9$ & 0 & Kurang \\
\hline $0-39,9$ & 0 & Sangat Kurang \\
\hline Jumlah & 20 & \\
\hline
\end{tabular}

Berdasarkan hasil pretest materi persamaan garis singgung lingkaran di atas maka peneliti melakukan tindakan dengan menerapkan model pembelajaran discovery learning pada siswa.

\section{Hasil Tindakan Siklus I}

Data pada Penelitian Tindakan Kelas ini merupakan data hasil tes pada pelaksanaan pembelajaran pada siklus I dan pelaksanaan pembelajaran pada siklus II dengan proses pembelajaran menggunakan discovery learning. Pelaksanaan tindakan dalam penelitian siklus I ini dilaksanakan pada semester II tahun ajaran 2018/2019, yaitu minggu pertama bulan Februari 2019. Pelaksanaan tindakan dan pengamatan dilakukan sesuai pembelajaran berlangsung dikelas XI IPA 4. Berdasarkan perencanaaan yang telah dibuat, pada pelaksanaan tindakan guru telah menyiapkan RPP, LKPD serta lembar instrumen yang diperlukan untuk kegiatan pembelajaran.

Kegiatan pembelajaran diawali dengan guru memberikan motivasi terkait materi yang akan diajarkan, yaitu persamaan garis singgung lingkaran. Kemudian dilanjutkan dengan apersepsi terkait materi. Pada kegiatan inti, siswa belajar bersama kelompok berkerjasama untuk menyelesaikan masalah terkait persamaan garis singgung lingkaran yang berpusat pada titik $(0,0)$ dan titik singgung $\mathrm{A}\left(x_{1}, y_{1}\right)$.

Pembagian kelompok dilakukan oleh peneliti berdasarkan posisi duduk siswa, satu kelompok terdiri dari 4-5 orang siswa. Pada pelaksanaannya, kegiatan pembelajaran berdasarkan tahapan model discovery learning. Pada LKPD yang telah dibagikan didalamnya diawali suatu masalah, siswa diberikan kesempatan untuk mengeksplorasi kemampuan menyesaikan masalah mereka secara berkelompok. Pada siklus pertama dilaksanakan observasi yang dilakukan oleh observer untuk mengamati aktivitas siswa dalam proses pembelajaran. Adapun aspek yang diamati diantaranya, yaitu Rasa Ingin Tahu, Percaya Diri, dan Bertanggung jawab. Berikut hasil observasi yang disajikan pada Tabel 2 .

Tabel 2. Hasil Observasi Siklus I

\begin{tabular}{ccc}
\hline Aspek & Jumlah Siswa & Persentase \\
\hline Ingin tahu & 8 & $40 \%$ \\
\hline Percaya diri & 10 & $50 \%$ \\
\hline Tanggung jawab & 12 & $60 \%$ \\
\hline
\end{tabular}

Available online at journal homepage: http://ejournal.iainkerinci.ac.id/index.php/edumatika Email: edumatika@iainkerinci.ac.id 
Berdasarkan tabel diatas, dari 20 siswa yang mengikuti kegiatan pembelajaran yang dilakukan, $40 \%$ siwa sudah timbul rasa ingin tahu , 50\% sudah percaya diri dalam bekerja kelompok, dan $60 \%$ siswa sudah bertanggung jawab terhadap tugas dalam kelompoknya. Berdasarkan kegiatan pembelajaran yang dilakukan pada pertemuan pertama, masih terdapat beberapa siswa yang belum memahami materi prasyarat terkait materi yang akan diajarkan. Hal ini terlihat siwa masih mengalami kesulitan dalam mengubah permasalahan yang diberikan ke dalam bentuk umum persamaan garis singgung lingkaran yang berpusat pada titik $(0,0)$ dan titik singgung $\mathrm{A}\left(x_{1}, y_{1}\right)$.

Kemudian, selain dilakukannya observasi dalam dalam penelitian ini dilakukan evaluasi setalah dilaksanakannya kegiatan pembelajaran sebagai acuan berhasil atau tidaknya penelitian yang dilakukan berdasarkan indikator keberhasilan yang telah dibuat. Nilai kemampuan pemecahan masalah siswa pada siklus I setelah dikonversikan disajikan pada Tabel 3.

Tabel 3. Kemampuan Pemecahan Masalah Siklus I

\begin{tabular}{ccc}
\hline Rentang Nilai & Jumlah Siswa & Kriteria \\
\hline $80-100$ & 6 & Sangat Baik \\
\hline $66-79,9$ & 10 & Baik \\
\hline $56-65,9$ & 4 & Cukup \\
\hline $40-55,9$ & 0 & Kurang \\
\hline $0-39,9$ & 0 & Sangat Kurang \\
\hline Jumlah & 20 & - \\
\hline
\end{tabular}

Berdasarkan Tabel 3 pada siklus I yang dilaksanakan, rata-rata yang diperoleh pada hasil tersebut adalah 78,8. Akan tetapi, siswa dikatakan belum bisa memecahkan masalah karena hasil yang dicapai hanya $80 \%$ siswa yang tuntas dari jumlah siswa yang terdapat di kelas. Berdasarkan hasil tersebut, indikator keberhasilan pada penelitian ini belum tercapai sehingga dilanjutkan siklus II.

\section{Hasil Refleksi Siklus I}

Pada pelaksanaan tindakan siklus I, terdapat beberapa kelemahan pada proses pembelajarannya, yaitu masih banyak siswa yang belum memahami materi prasyarat terkait materi yang akan diajarkan yaitu persamaan lingkaran dengan pusat $(0,0)$ dan persamaan lingkaran dengan pusat $(\mathrm{a}, \mathrm{b})$. Selain itu juga kurangnya waktu untuk dilasanakannya latihan soal.

Akan tetapi, jika dibandingkan dengan ketuntasan hasil belajar secara klasikal sebelum diadakannya tindakan, yaitu sebesar 30\%, hasil tes pada siklus I ini sudah mengalami peningkatan, yaitu $80 \%$. Maka dari itu, diperlukannya pembelajaran dengan discovery learning ini dilanjutkan ke siklus II dengan perbaikan berdasarkan hasil refleksi pada siklus I.

\section{Hasil Tindakan Siklus II}

Pelaksanaan tindakan dalam penelitian pada siklus II ini dilaksanakan minggu ketiga bulan Februari 2019. Pelaksanaan tindakan dan pengamatan dilakukan sesuai pembelajaran berlangsung dikelas XI IPA 4. Berdasarkan hasil refleksi pada siklus I, pada pelaksanaan tindakan guru juga menyiapkan Rencana Pelaksanaan Pembelajran (RPP), Lembar Kerja Peserta Didik (LKPD) serta lembar instrumen yang diperlukan untuk kegiatan pembelajaran. Pada LKPD yang telah dibagikan 
di dalamnya diawali suatu masalah, siswa diberikan kesempatan untuk eksplorasi kemampuan menyesaikan masalah mereka secara berkelompok.

Pada siklus kedua dilaksanakan juga observasi yang dilakukan oleh observer untuk mengamati aktivitas siswa dalam proses pembelajaran adapun aspek yang diamati diantaranya, yaitu Rasa Ingin Tahu, Percaya Diri, dan Bertanggung jawab. Berikut hasil observasi yang disajikan pada Tabel 4.

Tabel 4. Hasil Observasi Siklus II

\begin{tabular}{ccc}
\hline Aspek & Jumlah Siswa & Persentase \\
\hline Ingin tahu & 14 & $70 \%$ \\
\hline Percaya diri & 17 & $85 \%$ \\
\hline Tanggung jawab & 17 & $85 \%$ \\
\hline
\end{tabular}

Berdasarkan tabel diatas, dari 20 siswa yang mengikuti kegiatan pembelajaran yang dilakukan, $70 \%$ siswa sudah banyak memunculkan rasa ingin tahu, $85 \%$ sudah percaya diri secara berkelompok, dan $85 \%$ bertanggung jawab terhadap kelompoknya. Kemudian, selain dilakukannya observasi dalam dalam penelitian ini dilakukan evaluasi setalah dilaksanakannya kegiatan pembelajaran sebagai acuan berhasil atau tidaknya penelitian yang dilakukan berdasarkan indikator keberhasilan yang telah dibuat. Hasil belajar siswa pada siklus II tersaji pada Tabel 5 .

Tabel 5. Kemampuan Pemecahan Masalah Siklus II

\begin{tabular}{ccc}
\hline Rentang Nilai & Jumlah Siswa & Kriteria \\
\hline $80-100$ & 16 & Sangat Baik \\
$66-79,9$ & 4 & Baik \\
\hline $56-65,9$ & 0 & Cukup \\
\hline $40-55,9$ & 0 & Kurang \\
\hline $0-39,9$ & 0 & Sangat Kurang \\
\hline Jumlah & 20 & - \\
\hline
\end{tabular}

Berdasarkan hasil belajar siswa yang dikonversikan ke kemampuan pemecahan masalah siswa pada siklus II yang dilaksanakan, rata-rata yang diperoleh pada hasil tersebut adalah 93,6 Kemudian siswa dikatakan tuntas secara klasikal mencapai $100 \%$ dari jumlah siswa yang terdapat di kelas. Dengan kata lain, terjadi peningkatan hasil belajar sebesar $20 \%$ dari siklus I.

\section{Hasil Refleksi Siklus II}

Berdasarkan hasil tes pada siklus II, diperoleh nilai rata-rata kelas sebesar 93,6 Dari 20 siswa, terdapat 0 siswa yang belum tuntas dan 100 siswa sudah tuntas. Kemudian ketuntasan klasikal yang diperoleh sebesar $100 \%$. Berdasarkan hasil tersebut, indikator keberhasilan pada penelitian ini telah tercapai sehingga penelitian tindakan kelas diakhiri pada siklus II.

\section{Pembahasan}

Hasil pengamatan dari siklus I dan siklus II menunjukkan bahwa terjadi peningkatan persentase aspek rasa ingin tahu, percaya diri, dan tanggung jawab siswa. Pada siklus I persentase rasa ingin tahu siswa adalah $40 \%$ meningkat pada siklus II menjadi $70 \%$, persentase aspek percaya diri siswa pada siklus I sebesar 50\% meningkat menjadi 85\%, begitupula dengan persentase aspek 
tanggungjawab siswa pada siklus I sebesar $60 \%$ meningkat menjadi $85 \%$. Peningkatan setiap aspek pada siswa ini terjadi dikarenakan pembelajaran dengan menggunakan model discovery learning menuntut siswa untuk lebih memunculkan rasa ingin tahu untuk memecahkan permasalahan yang diberikan oleh guru, pembelajaran dengan model ini juga menuntut siswa percaya diri dan bertanggung jawab dalam penyelidikan kelompok.

Berdasarkan penelitian yang telah dilakukan, secara umum model discovery learning dapat meningkatkan kemampuan pemcahan masalah siswa. Hal ini terlihat dari hasil tes pada siklus I dan siklus II pada Tabel 6.

Tabel 6. Kemampuan Pemecahan Masalah Siklus I dan Siklus II

\begin{tabular}{ccccc}
\hline & \multicolumn{2}{c}{ Siklus 1 } & \multicolumn{2}{c}{ Siklus II } \\
\cline { 2 - 5 } & Rata-rata & Persentase (\%) & Rata-rata & Persentase (\%) \\
\hline Hasil Belajar & 78,8 & $80 \%$ & 93,6 & $100 \%$ \\
\hline
\end{tabular}

Berdasarkan tabel diatas, kemampuan pemecahan masalah siswa materi persamaan garis singgung lingkaran setelah diterapkan model pembelajaran discovery learning mengalami peningkatan dari rata-rata pada siklus I sebesar 78,8 dengan persentase siswa $80 \%$ meningkat pada siklus II dengan rata-rata 93,6 dan persentase siswa $100 \%$.

Pada siklus I terdapat 16 siswa yang tuntas dan 4 siswa yang belum tuntas. Pada siklus I terlihat bahwa ketuntasan klasikal pada siklus I belum mencapai target, yaitu 85\%. Hal ini dikarenakan masih terdapat kelemahan pada penerapan strategi pembelajaran yang digunakan. Adapun kelemahan yang diperoleh dari hasil refleksi pada siklus I adalah masih banyak siswa yang belum memahami materi prasyarat terkait materi yang akan diajarkan dan kurangnya waktu untuk dilasanakannya latihan soal. Maka untuk memperbaiki kelemahan yang terjadi pada siklus I dibuat rencana tindakan perbaikan pada siklus II. Diantaranya peneliti lebih memantapkan lagi materi prasyarat persamaan lingkaran dengan meminta siswa untuk mempelajari dan membaca kembali materi prasyarat tersebut. Adapun tindakan perbaikan mengenani permasalahan waktu peneliti akan memanfaatkan waktu belajar sesuai dengan perencanaan yang telah dibuat sebelumnya.

Pada siklus II dilakukan perbaikan berdasarkan refleksi pada siklus I. Pada siklus II diperoleh rata-rata hasil belajar siswa sebesar 93,6\% dengan persentase ketuntasan siswa sebesar $100 \%$. Terdapat 20 siswa yang tuntas dan 0 siswa yang tidak tuntas. Rata-rata hasil belajar siswa pada siklus II mengalami peningkatan sebesar 14,8\% dan ketuntasan belajar secara klasikal sebesar 20\% dari siklus I. persentase ketuntasan klasikal siswa juga sudah mencapai ketuntasan klasikal minimal yaitu 85\% siswa mendapatkan nilai diatas KKM yaitu 70. Peningkatan hasil belajar siswa ini dapat dicapai dikarenakan penerapan model pembelajaran discovery learning dengan perbaikanperbaikan berdasarkan hasil refleksi pada siklus I. Pada siklus II siswa sudah memahami materi prasyarat persamaan lingkaran dan juga suasana kelas menjadi lebih kondusif dikarenakan siswa menjadi lebih ingin tahu dalam pembelajaran, percaya diri dalam mempresentasikan hasil kelompok, dan bertanggungjawab dalam kelompoknya (Rosdianwinata, 2015).

\section{KESIMPULAN}

Kesimpulan pada penelitian ini adalah terdapat peningkatan kemampuan pemecahan masalah siswa dengan menerapkan model pembelajran discovery learning di kelas XI IPA 4 SMA Negeri 1 Palembang. Peningkatan kemampuan pemecahan masalah dapat dilihat dari rata-rata kemampuan pemecahan masalah siswa yang sebelum dilakukan tindakan memperoleh nilai rata-rata 58,2 dengan persentase ketuntasan $0 \%$ meningkat menjadi 78,8 dengan persentase ketuntasan $80 \%$ pada 
siklus I, dan meningkat lagi menjadi 93,6 dengan persentase ketuntasan 100\% pada siklus II. Peningkatan aspek ingin tahu siswa juga meningkat dari persentase $40 \%$ pada siklus I meningkat menjadi $70 \%$ pada siklus II, selain itu aspek percaya diri meningkat dari persentase $50 \%$ pada siklus I menjadi $85 \%$ pada siklus II, dan juga aspek tanggung jawab siswa juga meningkat dari persentase $60 \%$ pada siklus I menjadi $85 \%$ pada siklus II.

\section{DAFTAR RUJUKAN}

Ahmad, B., Deswita, R., Ningsih, F., \& Syafriadi, S. (2018). Pengaruh Model Pembelajaran CORE dengan Pendekatan Scientific Terhadap Kemampuan Pemecahan Masalah Matematis dan Mathematical Habits of Mind Mahasiswa Matematika. Tarbawi: Jurnal Ilmu Pendidikan, 13(2), 33-42.

Ariyanto, L., Aditya, D., \& Dwijayanti, I. (2019). Pengembangan Android Apps Berbasis Discovery Learning Untuk Meningkatkan Pemahaman Konsep Matematis Siswa Kelas VII. Edumatika: Jurnal Riset Pendidikan Matematika, 2(1), 40-51. doi:10.32939/ejrpm.v2i1.355

Effendi, L. A. (2012). Pembelajaran Matematika dengan Metode Penemuan Terbimbing untuk Meningkatkan Kemampuan Representasi dan Pemecahan Masalah Matematis Siswa SMP. Jurnal Penelitian Pendidikan, 13(2), 1-10.

Elita, G. S., Habibi, M., Putra, A., \& Ulandari, N. (2019). Pengaruh Pembelajaran Problem Based Learning dengan Pendekatan Metakognisi terhadap Kemampuan Pemecahan Masalah Matematis. Mosharafa: Jurnal Pendidikan Matematika, 8(3), 447-458.

Gunawan, R. G., \& Putra, A. (2019). Pengaruh Strategi Belajar Aktif Sortir Kartu Terhadap Kemampuan Pemecahan Masalah Matematis. Jurnal Cendekia: Jurnal Pendidikan Matematika, 3(2), 362-370.

Muhamad, N. (2017). Pengaruh Metode Discovery Learning untuk Meningkatkan Representasi Matematis dan Percaya Diri Siswa. Jurnal Pendidikan UNIGA, 10(1), 9-22.

Putra, A., Syarifuddin, H., \& Zulfah, Z. (2018). Validitas Lembar Kerja Peserta Didik Berbasis Penemuan Terbimbing dalam Upaya Meningkatkan Pemahaman Konsep dan Kemampuan Penalaran Matematis. Edumatika: Jurnal Riset Pendidikan Matematika, 1(2), 56-62. doi:10.32939/ejrpm.v1i2.302

Rhamayanti, Y. (2019). Peningkatan Hasil Belajar Matematika dan Respon Siswa Melalui Pembelajaran Kooperatif Tipe STAD dengan Metode Penemuan Terbimbing. Edumatika: Jurnal Riset Pendidikan Matematika, 2(1), 29-39. doi:10.32939/ejrpm.v2i1.244

Rosdianwinata, E. (2015). Penerapan Metode Discovery untuk Meningkatkan Kemampuan Pemecahan Masalah Matematika Siswa. MENDIDIK: Jurnal Kajian Pendidikan Dan Pengajaran, 1(1), 1-8.

Sahrudin, A. (2014). Implementasi Strategi Pembelajaran Discovery untuk Meningkatkan Kemampuan Pemecahan Masalah Matematis dan Motivasi Belajar Siswa SMA. JUDIKA (Jurnal Pendidikan Unsika), 2(1).

Sutrisno, L. (2016). PISA 2015. Pontianakpost. 11 Desember 2016. http://www.pontianakpost.co.id/pisa2015. Diakses pada tanggal 2 Desember 2018.

Wasilah, I., Murini, \& Jalinus. (2018). Pengembangan Perangkat Pembelajaran Matematika Melalui Penerapan Model Discovery Learning Pada Materi Lingkaran Untuk Siswa Kelas XI. Jurnal Pendidikan Universitas Riau. 